\title{
The Development Path of Low-carbon Economy from the Perspective of
}

\section{Marxist Ecological Philosophy}

\author{
Han $\mathrm{Gao}^{1}$ \\ ${ }^{1}$ Harbin University of Science and Technology, College of Marxism Harbin, Heilongjiang, 150080
}

Keywords: Marxist ecological philosophy; Low-carbon economy; Development path

\begin{abstract}
With the economic development in all countries and the deteriorating relationship between economy and environment, the implementation of low-carbon economy has become an inevitable choice for the national development, which means that we need to explain low-carbon economy from economic theories. Traditional Western mainstream economics ignored low-carbon economyin terms of the scope and the fundamental theories. Based on the author's learning and teaching experience for many years, this article first interprets low-carbon economy in Marx's economic theory and proposesdevelopment measures of low-carbon economy from the perspective of Marxist ecological philosophy.
\end{abstract}

\section{Introduction}

Global warming and the deterioration of natural environment make human development faced with very serious ecological challenges. In order to ease the contradiction between economic development and environmental protection, and achieve coordinated and sustainable development between economy,society and natural environment, low-carbon economy emerges and increasingly becomes a trend of global economic development. As a new model of economic development, low-carbon economy cannot function without the guidance of Marxist ecological philosophy.Delving into the ecological views of Marxist ecological philosophy has important practical significance to the development of low-carbon economy.

\section{Low-carbon Economy Thoughts in Marx's Economic Theory}

A discussion of the harmonious development between man and nature. Marxist economic theory is based essentially on the historical materialism. As a scientific development view, it reveals the studying problem of low-carbon economy --- human, nature, society, environment and their mutual relations.Marxistworks have long regarded nature, man and society as a unified organic whole and explore the objective laws of social development of human beingfrom this organic whole. It discusses the human dependence on natureand this is the gist oflow carbon economy. Marx said: "workers cannot create anything without nature and perceptualexternal world." Marx affirms clearly the priority of nature. Marxist economic theory has made clear that if the emission of waste in production and social life exceeds self cleaning capacity of natural ecosystem and ecological cycle is blocked, there will be vicious cycle of ecological economy with environmental pollution and ecological imbalance.

A discussion of lowemission. There are a lot of lowcarbon economy thoughts aboutlowemission in Marxist economic works. For example, in the Volume III of Das Kapital,Marx proposed solutions to reduce production excreta. Marx pointed out that the production excreta that we are talking about is industrial and agricultural waste; consumptionexcreta partly refers to excreta in 
human natural metabolism and partly refers to excreta of goods consumption. If we cannot addressboth excreta and directly discharge both into the environment, the ecological environment will be damaged and environment will be polluted. Marx proposed some suggestions of how to reduce consumptionexcreta. He pointed that consumptionexcreta is the most important in agriculture, which refers to the use of organic fertilizer in agricultural production to maintain the soil and protect the environment. Marx emphasized on resource conservation and the reuse of waste in production and life in Das Kapital. This will ultimately reduce emissions and form the basic low emission thought in low-carbon economy.

A discussion of improving waste and energy utilization. Marx pointed out that after the product itself has joined consumption... just as the consumptive waste and as the residual in consumption process, this can serve as means of production to rejoin other fields of production. This reflects the principle of waste recycling, which means to improve utilization of raw materials and auxiliary materials directly added into the production. This reflects the thought to maximize energy efficiency. In order to achieve a virtuous cycle of the ecological economic system, it is necessary to reduce pollutant emission, take waste as raw material and turn bane into boon. Marx also pointed out that the waste utilization is expanded with the expansion of production mode and the utilization of consumption and production excreta is expanded with the development of the capitalist production mode. In Marx's view, the waste recycle is a product ofsocialized mass production.

A discussion of achieving low-carbon economy which relies on science and technology progress. Marxist economic worksreflected his emphasis on science and technology. He noted that scientific and technological progress provides a new approach and a new way to reuseexcreta. Marx pointed out that the machine improvement makes these useless materials in the original form utilized to obtain new forms; the scientific progress, especially progress in chemistry, discovered the useful properties of those wastes. He clearly pointed out the importance of scientific and technological progress in the realization of recycle materials. The original waste has become a new resource.

\section{The Development Measures of Low-carbon Economy from the Perspective of Marxist Ecological Philosophy}

Take the harmonious development between man and nature as the core value of low-carbon economy. Marxist ecological philosophy emphasized that human beings have the right toutilize the natural environment for their survival and have the obligation to protect it.Regardless of the use or protection, human must be in full compliance with the objective laws of nature and strive to achieve harmonious development between human and nature. Human must be kind to nature and deal with relationship between man and nature in a reciprocity and mutual benefit way to eventually establish a new, harmonious,equal and coordination relationshipbetween man and nature.As a new model of economic development,low-carbon economy should take the harmonious development of man and nature as the core valueof its development, plan the coordinated development of economy, society and nature as a whole, and reflect the care of value rationality. Therefore, in the development of low-carbon economy, we should combinehuman subjectivity and the objective laws of nature with a respect for nature and lifeinstead ofanthropocentrism; we should use developing, general and related dialectical worldview to replace the still, one-sided and isolated one; we should take nature as a systematical whole to instead of the mechanical way of thinking and promote thedevelopment of low-carbon economy with the overall harmony between man and nature.

Take the ecological production mode as the a productionorientation of low-carbon economy. Marxist ecological philosophy believes that theintermediary agent of the dialectical unification 
relation is the human production practical activity, the key problemof which is how to achieve the metabolism between man and nature in the most worthy and suitable way.That means how to achieve harmonious development between man and nature in the human production practical activity. The realization of this goalrelies on the transformation of the production mode. Marx believed that human beings are differentiated from nature on the basis of labor and it is the production mode of material goods that determines the concrete and historical unity between society and nature. Therefore, we must take the ecological production mode as the production orientation of low-carbon economy.

The production mode of the traditional industrial economy is to maximize the development and utilization of natural resources, pursuethe profit maximization and maximize social wealth. The ecological production mode is in full consideration of the limited natural resources to conserve natural resources as much as possible. Moreover, it means to adjust the industrial structure based on objective laws of energy cycle in natural environment, improve the production process, developclean and renewable energy, constantly improve the utilization efficiency of resources, recycle resources, foster the development of appropriate recovery production industryand create sustainable social wealth. In the process of developing low-carbon economy, first of all, develop a recycle and sustainable productive model - resources - products - waste - recycling, vigorously promote waste recycling and the development of green energy, and implement the principle of resource reduction and recycling of product waste.Secondly, pay attention to the rationality of production planning and incorporate limited natural resources into production planning. We should optimize industrial structure, build a new low-carbon industrial clusters, increase investment and support for low-carbon and high-techindustries, transform the high-carbon industries and develop the low-carbon services sector. Finally, change the production purpose. We should transform the traditional pursuit of economic benefitinto the pursuit of economic and eco-efficient development to achieve the harmonious development between man and nature.

Take the innovation of low-carbon technology as the fundamental driving force for the development of low-carbon economy. For Marx, science plays a catalytic and revolutionaryrole in the history. He believed that the level of technological development and the extent of its use in the production process is the major determinant of the development level of productivity.The improvement of industrial productionor the cultural level of workers depends on the development of science and technology. Therefore, in the development of low-carbon economy, domestic and foreign scholars have made a basic consensus thatthe development and use of low-carbon technologies is a key to reduce emissions.

The innovation of low-carbon technology is a complex and systematical project andwe must make a systematical plan in terms of policies, regulations, the main body of innovation, personnel training and international cooperation. First, we must create the institutionalenvironment that is conducive to the development of low-carbon technology.The government should increasefinancial investment in low-carbon technology research, take preferential policies and bear some risks to attract social capital into low-carbon technology research. Moreover, the government shouldmake policiesto encourage the innovation of low-carbon technologyandimprove intellectual property legislations to protect the legitimate rights and interests of technical personnel. Secondly, strengthen the innovation dominant positionof enterprises and improve the market mechanism. We should change the main body of low-carbon technology research from universities and major research institutions to business. Furthermore, accelerate the transformation of scientific and technological achievements, achieve marketization of scientific and technological achievements and expand market share of low-carbon technological achievements in the world. Third, pay attention to the 
cultivation of innovative talents. Talent is the key of technological innovation. We should focus on cultivating low-carbon professional talents with full respect for the characteristics of innovative talents and create a good research environment for innovation. Finally, strengthen international cooperation, introduce foreign advanced technology and strengthen the international transfer of low-carbon technology.

Take the low-carbon systemand the cultivation of environmental awareness as the external power in low-carbon economy. Marx said: "politics is the concentrated expression of economics". Politics reflects the process of socio-economic development and the interests of various interest groups. The development of low-carbon economy requires are-definition of relations between man and man, man and nature and man and society and the construction of a new institutional system. The national policy guidance and participation of every citizen are inseparable parts of it.

First of all, the government should strengthen the long-term mechanism for the construction of low-carbon economy. First, we must increase the construction of incentive systems, such as the establishment of tax preference, preferential financing and other incentives to encourage the enterprises to develop low-carbon economy;second, we must improve the mandatory system, improve the relevant laws, regulations and standards system, regulate carbon trading market and improve the supervision and enforcement mechanisms to make low-carbon economy lawful; third, we must set up a specialized low-carbon economic development agencyto strengthen planning and development of low-carbon economy, so that we can make a reasonable planning and a unified deployment to achieve coordinated development; fourth, we must establish a mechanism for public participation. The government should actively listen to public opinions, correct mistakes and biased decisions to encourage mass supervision and promote enforcement fairness and rationality of laws. Secondly, foster universal low-carbon consciousness. Old ideas of natural resources and lack of crisis sense make peopleirresponsible for the low-carbondevelopment.Therefore, it is very important to foster low-carbon awareness.

\section{Conclusion}

Marxist ecological philosophy reveals the essence of the relationship between man and nature and the direction of harmonious development between man and nature. Currently, the development model of low-carbon economy is the sublimation of Marxist ecological philosophy with the times and it is a contemporary practice of Marxist ecological philosophy. In the development of low-carbon economy, we must adhere to the theoretical guidance of Marxism ecological philosophy. Under the guidance of scientific outlook on development, we should take the sustainable low-carbon development road to achieve comprehensive harmony between human, society and nature.

\section{References}

[1] Li Chunyan, Wang Gang. The Development of Low-carbon Economy from the Perspective of Marxist Ecological Philosophy[J].Journal of Heihe University, 2013,06: 22-25.

[2] Liao Zhidan, Chen Xicheng.Marx and Engels’ Ecological Philosophy: theWisdom Source of the Construction ofEcological Civilization in China [J].Guizhou Social Sciences, 2011,01: 9-13.

[3] Wang Xiaoyu.An Analysis of China's Economic Development Path Based on Marxism Ecological Thought [J].Ideological and Theoretical Education, 2011,13: 27-31.

[4] Gong Shuyan, Xia Weili. A Study of Marxist Ecological Philosophy in Low-carbon Economy [J]. Qinghai Social Sciences, 2011,03: 93-96. 
[5] Chang Qian.The Development Path of Low-carbon EconomyBased on Marxism Ecological Thought [J]. Theory Research, 2013,19: 35-36. 